\title{
The Correlation between Serum Concentration of Vitamin D with Vitamin D Receptor Expression and Disease Activity in Indonesian Patients with Systemic Lupus Erythematosus: Preliminary Study
}

\author{
Kusworini Handono ${ }^{1}$, Laksmi Karunia Tanuwijaya ${ }^{2 *}$, Loeki Enggar Fitri ${ }^{3}$, Handono Kalim ${ }^{4}$ \\ ${ }^{1}$ Department of Clinical Pathology, Faculty of Medicine, University of Brawijaya, Indonesia \\ ${ }^{2}$ Department of Nutrition, Faculty of Medicine, University of Brawijaya, Indonesia \\ ${ }^{3}$ Department of Parasitology, Faculty of Medicine, University of Brawijaya, Indonesia \\ ${ }^{4}$ Department of Internal Medicine, Faculty of Medicine, University of Brawijaya, Indonesia
}

\begin{abstract}
The vitamin $\mathrm{D}$ role on the immune response of systemic lupus erythematosus (SLE) patient is mediated by vitamin D receptor (VDR). Low level of vitamin D correlated with disease activity in SLE patients, and circulating levels of activated vitamin D (1,25(OH)2D) contribute to VDR protein levels and its function. The objective of this study was to determine the correlation between vitamin $\mathrm{D}$ status with expression of VDR in peripheral blood mononuclear cell (PBMC) and the disease activity in SLE patients. The Research Subjects were 15 SLE patients (ACR 1997 criteria) from the RheumatoImmunology Division, dr. Saiful Anwar Hospital, Malang and 5 healthy controls. Serum vitamin D (25(OH)D3) level was assessed using ELISA method. VDR expression in PBMC was assessed using immunocytochemistry technique. The disease activity was measured by Systemic Lupus Erythematosus Disease Activity Index (SLEDAI) score. This study showed no difference on VDR expression in PBMC between patient and healthy control group, but patient with vitamin D deficiency had lower VDR expression in PBMC than the other group. No difference on SLEDAI score between the group. Vitamin D status correlated positively with VDR expression in PBMC $(p<0,035, r=0,473)$. However vitamin $\mathrm{D}$ status did not correlate with disease activity scores $(\mathrm{p}=0,686)$.
\end{abstract}

Keywords: Systemic Lupus Erythematosus, vitamin D, VDR, disease activity

\section{INTRODUCTION}

Autoimmune diseases are among the leading causes of death in young and middle-aged women in the United States [1]. In Indonesia, the number of people with Systemic Lupus Erythematosus (SLE) is not known precisely, estimated to number 1.5 million people [2]. SLE patients in Indonesia still have low of life expectancy, at 5 years was $70 \%$ and 10 years by 55\% [3]. Many studies reported an association between low levels of vitamin $\mathrm{D}$ to onset of autoimmune diseases including SLE [4].

\footnotetext{
"Corresponding author:

Laksmi Karunia Tanuwijaya

Department of Nutrition, Faculty of Medicine, University of Brawijaya, Indonesia

E-mail: laksmi.karunia@gmail.com
}

These results are consistent with studies conducted in patients with SLE in Malang, Indonesia, which showed that the average of serum vitamin D levels were below normal (20.1 $+17.0 \mathrm{ng} / \mathrm{ml}$ ), and was significantly lower than in healthy controls [5].

Vitamin D is a steroid hormone with the effects on mineral metabolism, skeletal health, and recently known its effects on cardiovascular and immune health [6-8]. Low level of vitamin D is appears to be critical for autoimmune disease susceptibility and severity [9]. Many study demonstrated a negative correlation between $25(\mathrm{OH}) \mathrm{D}$ and disease activity (SLEDAI score) among SLE patients $[4,5]$. In research Mok, et al, found that the levels of $25(\mathrm{OH})$ D3 was negatively correlated with SLEDAI scores $(\beta$ $0.19, \quad \mathrm{P}=0.003)$, due to kidney disease, hematologic and musculoskeletal more active [10]. 
The role of vitamin $\mathrm{D}$ in the regulation of immune responses mediated by the presence of the vitamin $\mathrm{D}$ receptor (VDR) in the activated inflammatory cells [11]. Some studies found circulating levels of activated vitamin D $(1,25(\mathrm{OH}) 2 \mathrm{D})$ contribute to VDR protein levels [4,12-14]. In a study in patients with pulmonary tuberculosis was reported that an increase in the level of 1,25- $(\mathrm{OH}) 2 \mathrm{D} 3$, but the VDR protein levels decreased. Increased $1,25-(\mathrm{OH}) 2 \mathrm{D} 3$ may be possible to trigger the down regulation of VDR and will result low VDR signaling [15].

Vitamin D can be obtained from two sources, through diet or ultraviolet-mediated synthesis in the epidermal layer of skin. Two forms of vitamin $\mathrm{D}$ can be obtained from food, are vitamin D2 (ergocalciferol) found in fungi / yeast, whereas vitamin D3 (cholecalciferol) contained in animal foods [16]. Ultraviolet rays trigger the breakdown of the photolysis of 7-dihydrocholesterol (7-DHC) into pre-vitamin $\mathrm{D} 3$, which will form the vitamin D3 through thermal isomerization process spontaneously [17].

In terms of geographical location, Indonesia is at $6{ }^{\circ} \mathrm{NL}$ (North latitude) and $11{ }^{\circ} \mathrm{LS}$ (South latitude) and crossed the equator which indicates that Indonesia will be exposed to sunlight throughout the year, but according to a study reported that there were vitamin $\mathrm{D}$ deficiencies in females in all age groups in the Philippines, Malaysia, and Indonesia [4].

The role of vitamin D status on VDR and disease activity in Indonesian SLE patient remain unclear. Indonesia is one of tropical-climate country with nearly year-round excessive sun exposure, that supposed to be sufficient for vitamin D synthesis [4]. The objective of this study was to determine the correlation between vitamin D status with VDR expression in peripheral blood mononuclear cell (PBMC) and the disease activity in SLE patients.

\section{MATERIALS AND METHOD}

\section{Study Subjects}

This research was carried out with the approval of the Ethical Board of Medical Faculty Brawijaya University, Malang, East Java, Indonesia. Written informed consent was obtained from all study participants. The subject were 15 female with SLE (ACR 1997 classification)
$[18,19]$ followed up at Rheumatology clinic or admitted to Internal Medicine Department ward at Saiful Anwar Malang Hospital. The patients were new onset of SLE / received treatment less than 6 months, age between 18 years-premenopausal, pregnancy nor lactation, not using multi-vitamin supplement, able to speak and understand Indonesia language, and able and willing to give informed consent. As the control group were 5 healthy agematched female. All subjects underwent history and physical examination and measurement of serum concentration of $25(\mathrm{OH}) \mathrm{D} 3$ and expression of vitamin $\mathrm{D}$ receptor.

\section{Assessment of Vitamin D Level}

Serum was obtained from subject's blood sample; that were collected and stored in $-80^{\circ} \mathrm{C}$. The measurement of vitamin D $(25(\mathrm{OH}) \mathrm{D} 3)$ concentration was assayed using Enzyme-linked Immunosorbent Assay (ELISA) (Cusabio, Cat No.CSB-E08097h) in accordance with the manufacturer's instruction. Vitamin D levels considered as normal when the concentration of $25(\mathrm{OH}) \mathrm{D} 3$ were $>30 \mathrm{ng} / \mathrm{ml}$; insufficiency (15-30 $\mathrm{ng} / \mathrm{ml})$ and deficiency $(<15 \mathrm{ng} / \mathrm{ml})$.

\section{Isolation of Peripheral Blood Mononuclear Cells}

Peripheral blood mononuclear cells (PBMCs) were separated from whole blood of patients and healthy subjects that were collected in EDTA's tube. The separation using standard Ficoll-Hypaque density gradient centrifugation. The separated cells were fixed on microscope slide using 100\% methanol and stored at $4{ }^{\circ} \mathrm{C}$ for immunocytochemistry examination [20].

\section{Assessment of VDR Expression}

Expression of vitamin $\mathrm{D}$ receptor on peripheral mononuclear blood cell (PMBC) was assayed using immunocytochemistry method with specific polyclonal antibody to VDR (Novateinbio, Cat\# SH-A16772), by examining the appearance of brown colour (DAB chromogen) under microscope light on $1000 \mathrm{x}$ magnification.

\section{Assessment of SLE Activity}

Disease activity was measured with the Systemic Lupus Erythematosus Disease Activity Index (SLEDAI) using medical records, laboratory testing and personal interview and physical examination. This index consist of 24 items with total score $0-105$ [21]. All serological 
marker were assayed in Central Laboratory of General Hospital dr. Saiful Anwar Malang, Indonesia.

\section{Statistical Analysis}

The differences between VDR expression levels of the SLE patients with normal vitamin D status, vitamin $\mathrm{D}$ insufficiency, vitamin $\mathrm{D}$ deficiency, and healthy control were analysed using one-way ANOVA, after tested its normality using Shapiro-Wilk. For data non-normally distributed, appropriate transformations were performed. Correlation between vitamin $\mathrm{D}$ status with VDR expression and disease activity were analysed using Spearman correlation test, whereas correlation between VDR expression and disease activity were analysed using Pearson correlation test. A p-value of $<0.05$ was considered significant. All calculations performed with the software of SPSS for Windows 16.0.

\section{RESULTS AND DISCUSSION}

In this study there was no difference on age and body mass index (BMI) between patient and healthy control group. Age of the sample was 30 $\pm 8,9$ year for SLE patient and $33 \pm 3,7$ year for healthy control (mean \pm SD). Body mass index (BMI) was 22,83 \pm 5,1 for SLE patient and 19,16 $\pm 0,9$ for healthy control (mean $\pm \mathrm{SD}$ ). High disease activity of SLE patient was found in 7 patient $(46,67 \%)$. The samples mean of age in this study was $30 \pm 8,9$ year, indicated that those were in productive ages. A study held on 2003 to 2008 found that SLE incidence was $91,72 \%$ occurred between $18-64$ years [22].
Result of this research showed that 53,3\% SLE patient had normal body mass index, our result confirmed those of Attar, et al, [23] who also found that $30 \%$ of SLE patient had normal body mass index and 33\% SLE patient had overweight and obesity $(\mathrm{n}=95)$. The increasing of body mass index correlate with age, low social support, and depression (OR 1.091, 95\% confidence interval 1.026-1.159, $\mathrm{p}=0.005)$, but not correlate to disease activity, and patient quality of life [24].

Low level of vitamin D is prevalent in SLE patient. Previous study showed that the average vitamin $\mathrm{D}$ level in SLE patients was below normal $(20.1+17.0 \mathrm{ng} / \mathrm{ml})$, and significantly lower in comparison to the healthy control [5]. Patients with SLE have multiple risk factors for $25(\mathrm{OH}) \mathrm{D}$ deficiency. Photosensitivity, characteristic of the disease, and the recommen-dation to apply sunscreen are responsible for lower sun exposure, those factor contribute to the decreasing of vitamin D production in the skin [25].

One of reasons of why hypovitaminosis D can be a cause of SLE is the presence of evidence that vitamin $\mathrm{D}$ has a role in the regulation of the immune system that prevents autoimmunity. Vitamin D receptor that is expressed in various cells in the immune system [26], 1,25(OH)2D3 can regulate the activity of $\mathrm{T}$ cells either directly or indirectly through modulation of APC function [27] and 1,25(OH)2D3 directly suppress the code transcription process of cytokine genes associated with Th1 [28].

Positive VDR expression in PBMC was seen in patient and healthy control (expressed in brown color) and the number of cell expressed VDR was differ between group. We found no difference of VDR expression in PBMC between

Table 1. VDR expression and SLEDAI score in healthy control and patient with SLE based on vitamin D status

\begin{tabular}{lccc}
\hline \multicolumn{1}{c}{ Subject } & $\begin{array}{c}\text { Vitamin D level } \\
(\mathrm{ng} / \mathrm{ml}) \\
(\text { mean } \pm \mathrm{SD})\end{array}$ & $\begin{array}{c}\text { VDR expression }(\%) \\
(\text { mean } \pm \mathrm{SD})\end{array}$ & $\begin{array}{c}\text { SLEDAI score } \\
(\text { mean } \pm \mathrm{SD})\end{array}$ \\
\hline Healthy control $(\mathrm{n}=5)$ & $37,5 \pm 4,0$ & $42,49 \pm 9,1$ & - \\
Patient with SLE & & & \\
$\quad$ Normal Vitamin D $(\mathrm{n}=5)$ & $36,0 \pm 5,9$ & $45,59 \pm 1,5$ & $11,2 \pm 6,6$ \\
Vitamin D insufficiency $(\mathrm{n}=5)$ & $23,5 \pm 2,7$ & $37,56 \pm 1,8$ & $8,6 \pm 4,7$ \\
Vitamin D deficiency $(\mathrm{n}=5)$ & $13,8 \pm 6,0$ & $28,85 \pm 1,9$ & $12,8 \pm 4,6$ \\
& & & \\
\hline
\end{tabular}


patient and healthy control group however patient with vitamin $\mathrm{D}$ deficiency tend to have lower VDR expression than the other group (Table 1). Patients with low level of vitamin D tended to have lower VDR expression compared to patient and healthy control with normal vitamin $\mathrm{D}$ status. This result confirmed to Ogunkolade, et al, that circulating levels of activated vitamin $\mathrm{D}(1,25(\mathrm{OH}) 2 \mathrm{D})$ to contribute to VDR protein levels [12].

Vitamin D receptor is found in abundant concentrations in the $\mathrm{T}$ lymphocyte and macrophage, and the highest concentration is in the immature immune cells of the thymus and the mature CD-8 T lymphocytes [30]. A clinical study reported that $76 \%$ seropositive patients with rheumatoid arthritis had lymphocytes that possessed VDR (without in vitro activation) compared to only $18 \%$ (3 of 17) in normal individuals [31].

Our study showed that vitamin $\mathrm{D}$ status positively correlated with VDR expression ( $\mathrm{p}=$ $0,035 ; \mathrm{r}=0,473)$. It has been demonstrated that $1,25-(\mathrm{OH}) 2 \mathrm{D} 3$ stabilizes the receptor when bound each other and 1,25-(OH)2D3 prevents inactivation of its receptor during purification [32]. This could be due to $1,25-(\mathrm{OH}) 2 \mathrm{D} 3$ protected its receptor from proteolytic attack from endogenous proteases present in the extracts. These enzymes may also function in intact cells [32].

Disease activity score in SLE patient with vitamin $\mathrm{D}$ deficiency ranged from 8 to 18 , in SLE patients with vitamin $\mathrm{D}$ insufficiency ranged from 2 to 14, the disease activity in SLE patient with normal vitamin D status ranged from 4 to 18. We found no significant correlation between vitamin $\mathrm{D}$ status and disease activity scores group $(p=0,483)$. However we found that the patient with vitamin $\mathrm{D}$ deficiency tend to have higher SLEDAI scores than others, even there is no significant difference between group. Confirmed to Mok et al., we found that 25(OH)D3 level negatively correlated with SLEDAI scores $(\beta$ 0.19; $\mathrm{P}=0.003)$, due to more active renal disease, musculoskeletal and hematologic disease.

The study suggested that low level of 25(OH)D3 be correlated with B cell hyperactivity and increased autoantibodies production, but not related to complement activation [10]. Previous studies have yielded conflicting evidence for a relationship between 25-hydroxyvitamin D3 level and SLE disease activity. The result is attributed to many factors, such as inadequate sample size, seasonal variation of vitamin $\mathrm{D}$ levels, and the small proportion of participants with active SLE recruited into the research [33].

We found that the SLEDAI score did not correlate with VDR expression, but patient with lower VDR expression seemed to have higher SLEDAI score. TB patient significantly had lower VDR protein than the healthy control. The decreasing of VDR protein in TB patient might be due to VDR expression down-regulation as a result from increasing of $1,25(\mathrm{OH}) 2 \mathrm{D} 3$ synthesis $[15,34]$. The decrease might lead to defective VDR signalling due to the unavailibity of receptors for $1,25(\mathrm{OH}) 2 \mathrm{D} 3$. Defective VDR signalling might result in the increased inflammation due to the increased expression of inflammatory cytokines [15].

\section{CONCLUSIONS}

Vitamin D status significantly correlated with VDR expression in PBMC, and VDR expression in PBMC did not correlate with disease activity scores. A limitation of this study was in its sample size. This research indicates that the vitamin $\mathrm{D}$ and its receptor played a role in autoimmune disease, especially in SLE.

\section{ACKNOWLEDGMENT}

This works was supported by Medical Faculty, University of Brawijaya Indonesia, and Parahita Foundation Malang, Indonesia. The author thank the SLE Research Team for their dedication to data collection for this study.

\section{REFERENCES}

1. Cooper GS, Stroehla BC (2003) The epidemiology of autoimmune diseases. Autoimmun Rev. (3): 119-25.

2. Musadad DA (2012) Penyakit Seribu Wajah. Badan Penelitian dan Pengembangan Kesehatan. Kementerian Kesehatan Republik Indonesia. http: //www.litbang.depkes.go.id/node/131. Accessed on May 2012. 
3. Handono K (2000) HLA klas II dan kerentanan genetik terhadap Lupus Eritematosus Sistemik di Indonesia. Acta Med Ind. XXXII: 11-5.

4. Haussler MR, Whitfield GK, Haussler CA, Hsieh JC, Thompson PD, Selznick SH (1998) The nuclear vitamin D receptor: biological and molecular regulatory properties revealed. J Bone Miner Res. 13(3): 325-49.

5. Handono K, Puspitasari L, Rudijanto A, Wahono S, Kalim H (2013) Vitamin D Serum Level And Disease Activity In Patients With Systemic Lupus Erythematosus. Int J Pharm Sci Invent. 2(2): 3540.

6. Al Mheid I, Patel R, Murrow J, Morris A, Rahman A, Fike L (2011). Vitamin D status is associated with arterial stiffness and vascular dysfunction in healthy humans. J Am Coll Cardiol. 58(2): 18692.

7. Zhao G, Ford ES, Li C, Croft JB (2012) Serum 25-hydroxyvitamin D levels and all-cause and cardiovascular disease mortality among US adults with hypertension: the NHANES linked mortality study. J Hypertens. 30(2): 284-9.

8. Aranow C (2011) Vitamin D and the immune system. J Investig Med Off Publ Am Fed Clin Res. 59(6): 881-6.

9. Cutolo M, Otsa K (2008) Review: Vitamin D, immunity and. Lupus. 17(1): 6-10.

10. Mok CC, Birmingham DJ, Leung HW, Hebert LA, Song H, Rovin BH (2012) Vitamin D levels in Chinese patients with systemic lupus erythematosus: relationship with disease activity, vascular risk factors and atherosclerosis. Rheumatol Oxf Engl. 51(4): 644-52.

11. Bikle D (2009) Nonclassic Actions of Vitamin D. J Clin Endocrinol Metab. 94(1): 26-34.

12. Ogunkolade BW, Boucher BJ, Prahl JM, Bustin SA, Burrin JM, Noonan K (2002) Vitamin D receptor (VDR) mRNA and VDR protein levels in relation to vitamin $\mathrm{D}$ status, insulin secretory capacity, and VDR genotype in Bangladeshi Asians. Diabetes. 51(7): 2294-300.

13. Bell NH (1998) Renal and nonrenal 25hydroxyvitamin D-1alpha-hydroxylases and their clinical significance. J Bone Miner Res Off J Am Soc Bone Miner Res. 13(3): 350-3.

14. Dusso AS, Finch J, Brown A, Ritter C, Delmez J, Schreiner G (1991) Extrarenal production of calcitriol in normal and uremic humans. J Clin Endocrinol Metab. 72(1): 157-64.

15. Selvaraj P, Anand SP, Harishankar M, Alagarasu (2009) Plasma 1,25 Dihydroxy Vitamin D3 Level and Expression of Vitamin D Receptor and Cathelicidin in Pulmonary Tuberculosis. J Clin Immunol. 29(4): 470-8.
16. Lamberg-Allardt C (2006) Vitamin D in foods and as supplements. Prog Biophys Mol Biol. 92(1): 33-8.

17. DeLuca HF (2004) Overview of general physiologic features and functions of vitamin $\mathrm{D}$. Am J Clin Nutr. 80(6): 1689S-1696S.

18. Tan EM, Cohen AS, Fries JF, Masi AT, McShane DJ, Rothfield NF (1982) The 1982 revised criteria for the classification of systemic lupus erythematosus. Arthritis Rheum. 25(11): 1271-7.

19. Hochberg MC (1997) Updating the American College of Rheumatology revised criteria for the classification of systemic lupus erythematosus. Arthritis Rheum. 40(9): 1725.

20. Fuss, I. J., Kanof, M. E., Smith, P. D. and Zola, H. (2009) Isolation of Whole Mononuclear Cells from Peripheral Blood and Cord Blood. Current Protocols in Immunology. 85:I:7.1:7.1.1-7.1.8.

21. Isenberg D, Ramsey-Goldman R (1999) Assessing patients with lupus: towards a drug responder index. Rheumatol Oxf Engl. 38(11): 1045-9.

22. Furst DE, Clarke AE, Fernandes AW, Bancroft T, Greth W, Iorga SR (2013) Incidence and prevalence of adult systemic lupus erythematosus in a large US managed-care population. Lupus. 22(1):99-105.

23. Attar SM, Siddiqui AM (2013) Vitamin D Deficiency in Patients with Systemic Lupus Erythematosus. Oman Med J. 28(1): 42-7.

24. Chaiamnuay S, Bertoli AM, Fernandez M, Apte M, Vila LM, Reveille JD (2007) The Impact of Increased Body Mass Index on Systemic Lupus Erythematosus: Data From LUMINA, a Multiethnic Cohort. JCR J Clin Rheumatol. 13(3): 128-33.

25. Marques CDL, Dantas AT, Fragoso TS, Duarte ÂLBP (2010) The importance of vitamin D levels in autoimmune diseases. Rev Bras Reumatol. 50(1): 67-80.

26. Adams JS, Hewison M (2008) Unexpected actions of vitamin D: new perspectives on the regulation of innate and adaptive immunity. Nat Clin Pract Endocrinol Metab. 4(2): 80-90.

27. Adorini L, Penna G (2009) Dendritic cell tolerogenicity: a key mechanism in immunomodulation by vitamin $\mathrm{D}$ receptor agonists. Hum Immunol. 70(5): 345-52.

28. Toubi E, Shoenfeld Y (2010) The role of vitamin $\mathrm{D}$ in regulating immune responses. Isr Med Assoc J IMAJ. 12(3): 174-5.

29. Wang Y, Zhu J, DeLuca HF (2012) Where is the vitamin D receptor? Arch Biochem Biophys. 523(1): 123-33.

30. Deluca HF, Cantorna MT (2001) Vitamin D: its role and uses in immunology. FASEB J. 15(14): 2579-85. 
31. Manolagas SC, Werntz DA, Tsoukas CD, Provvedini DM, Vaughan JH (1986) 1,25Dihydroxyvitamin D3 receptors in lymphocytes from patients with rheumatoid arthritis. J Lab Clin Med. 108(6): 596-600.

32. Wiese RJ, Uhland-Smith A, Ross TK, Prahl JM, DeLuca HF (1992) Up-regulation of the vitamin $\mathrm{D}$ receptor in response to 1,25 -dihydroxyvitamin D3 results from ligand-induced stabilization. J Biol Chem. 267(28): 20082-6.

33. Mok C, Birmingham D, Ho L, Hebert L, Song H, Rovin B (2011) Vitamin D deficiency as marker for disease activity and damage in systemic lupus erythematosus: a comparison with anti-dsDNA and anti-C1q. Lupus. 21(1): 36-42.

34. Lechner D, Kállay E, Cross HS (2007) 1alpha,25dihydroxyvitamin D3 downregulates CYP27B1 and induces CYP24A1 in colon cells. Mol Cell Endocrinol. 263(1-2): 55-64. 